DOI: https://doi.org/10.31392/NPU-nc.series9.2020.20.05

UDC: $81^{\prime} 01$

Lilia P. Kalytiuk

National Pedagogical Dragomanov University,

Kyiv, Ukraine

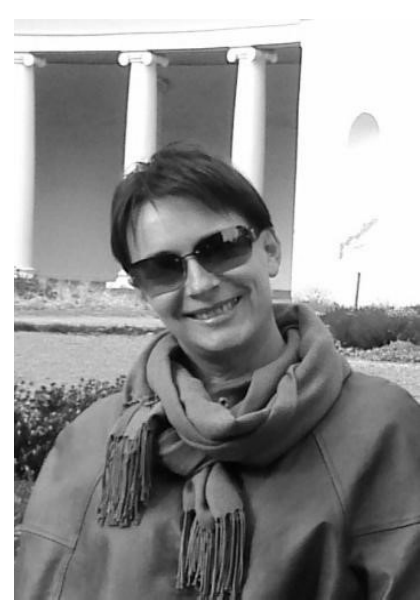

\title{
INFORMATION STRUCTURE OF COMPARISONS OF INEQUALITY IN OLD ENGLISH RIDDLES
}

\section{Bibliographic Description:}

Kalytiuk, L. P. (2020). Information Structure of Comparisons of Inequality in Old English Riddles. Scientific Journal of National Pedagogical Dragomanov University. Series 9. Current Trends in Language Development. 20. 64-74. https://doi.org/10.31392/NPUnc.series9.2020.20.05

\begin{abstract}
This investigation focuses on information packaging in comparative structures of inequality in Old English riddles in The Exeter Book dating back to the $10^{\text {th }}$ century. It is maintained that comparisons do not act as an economical way to introduce new information to the recipient, on the contrary the said structures serve the purpose of misleading, misdirecting, obscuring the riddllee and in doing so the riddler builds blocks which hinder the identification of the riddling entity. The latter though inanimate can take voices, selfpresenting through semantically diffuse personal deixis (known as prosopopoeia). Also the main canonical principle of information structure 'old comes before new' is violated in the said polipredicative sentences. The information packaging of comparisons of inequality in Old English riddles takes the form: 'unknown to the recipient + new but known from the previous experience'. The riddler wraps the information so that it involves the recipient's exophoric context, often culturally bound. Old Norse and Gothic comparisons are contrasted in order to shape the specificity of the Old English comparisons of inequality in riddling practice.
\end{abstract}

Keywords: comparisons of inequality, information packaging, information structure, Old English riddles, prosopopoeia.

\section{Introduction.}

When it comes to understanding general trends of language development, its earliest stages are considered to be most important because exceptionally valuable information comes from earliest written monuments however patchy they are. Luckily the Germanic group of languages boasts about relatively plentiful sources of language material covering the three subgroups: East (Gothic), West (predominantly Old English), and North (Old Norse) (hereinafter respectively Goth., OE, ON). The said languages supply the investigator with textual sources sufficient for comparison. Early written attestation of the languages in 
question is a good evidence of the syntactic processes at the earliest stages of development of the Old Germanic languages. The earliest attested runic inscriptions on artifacts are considered to follow the restrictions imposed by conventions of poetic tradition, requirements of style and arrangement and therefore provide sketchy information about a given language. Thus, however laconic the runic inscriptions might appear, they still reveal the basic sentence structure of Common Germanic as SOV, and highly paratactic (Lehman, 2005; 2007: 98; Buniyatova, 2003: 62) readily apparent to the naked eye in the famous runic inscription on the Gallehus horn:

(1) ek hlewagastiz holtijaz horna tawido.

$S$ [I Hlewagastiz of Holt] $O$ [horn] V [I-made]

'I, Hlewagastir of Holt, made the horn' (Lehman, 2007: 79).

Old Germanic hypotaxis is among the least investigated topics in Germanic linguistics. This article will be a modest contribution into diachronic syntax, also there is not much knowledge about Anglo-Saxon riddling practice, so this research will hopefully fill the information gap in this topic as well.

This investigation focuses on information packaging of OE comparisons of inequality in riddles from The Exeter Book compiled by the $10^{\text {th }}$-century Anglo-Saxon clerics. As Megan Cavell reasonably points, 'Anglo-Saxon riddling was not just a juvenile game or trivial exercise, but a prestigious literary genre in its own right' (Cavell, 2018 URL: https://www.bl.uk/medieval-literature/articles/the-exeter-book-riddles-in-context). It was an exercise for the mind for the chosen ones, not for lay people. Germanic culture was originally an oral culture and literacy is a by-product of Christianization and latinization. Thus, the tacitly accepted problem of early Germanic literary monuments is the degree of Latin interference (in the case of Gothic - Greek influence). Anglo-Saxon riddling tradition descended from the late-antique writer Symphosius; riddles were popularized by the scholar, churchman, and virtuosic poet and prose writer Aldhelm (ca. 639-709). The OE riddles in the renowned Exeter Book (Exeter Cathedral Library, ms. 3501) were probably written by various people; although they were most likely compiled sometime around the date of the manuscript ( $c$. 965-975), there are indications that some may date from as early as the eighth century (please, see for more details Stanton, 2015:29-43 URL: https://doi.org/10.1007/978-1-137-39706-5). The degree of Latin interference on OE poetry is considered by scholars to be small compared to prose (Möhlig-Falke, 2016, URL: https:/www.researchgate.net/publication/307852792). Alliteration, cesure and kennings are the defining features of Old Germanic poetry. The first two are also present in OE riddles together with abundant metaphors whose status as kennings still waits for insightful research as it is. The riddles in the said book are of poetic nature and therefore can be viewed as having small degree of Latin interference and may serve a reliable source of language material for this investigation. Modern historical syntactic studies are on their way to reach the level comparable to early Indo-Europeanists' investigation in phonology and morphology and allow syntactic findings to gain reliable explanatory power (e.g. W. Lehman's works in the field). But still there are relatively few topics in Early Germanic linguistics that are uncontroversial and well understood (for more details, please, see Fulk, 2018). The things are even less definite when it comes to polypredicative sentences, i.e. having one or more dependent clauses.

The novelty of the research is in applying theoretical issues of information structure of the sentence to diachronic syntax of $O E$ (comparisons of inequality in $O E$ riddles). The results will shed some light on the way the information was presented in Anglo-Saxon speaking community through comparisons of inequality in riddling tradition. To highlight the specifics of comparisons of inequality in Anglo-Saxon riddles, it is plausible to go the usual 
academic way: theoretical review, examples, conclusions. I shall start with issues relevant to comparative clauses, then I touch upon information packaging of the sentences in riddles. The findings of the carried out research are formulated in conclusions.

\section{Aim and Objectives.}

The aim of the article. The article seeks to highlight the particularities of comparative clauses in OE riddles.

\section{Objectives:}

- to analyze comparisons of inequality expressed by adjectives in comparative degree $[\mathrm{Adj}+\mathrm{er}]$ in OE riddles;

- to highlight the specificity of information structure of comparisons in OE riddles as contrasted with ON Edda (Völuspá (Codex Regius, ca $10^{\text {th }}$ c.) and The Gothic Bible (Codex Argenteus, $6^{\text {th }}$ c.);

- to determine the function of comparisons of inequality.

\section{Methodology.}

The methodological basis of the carried out research is information structure and information packaging of the sentence. Information structure has been described at length in different schools of thought (see Chafe W. L., 1976; Prince, A. 1981; Wilbur, R. 2012 inter alia). The primary attention is given to allocation of old and new information in the sentences containing comparisons of inequality. In the article it is assumed uncritically that the structure of the comparison contains three obligatory members (subject, object and basis) and the optional one (the marker). This article is arranged to fill the gap in our knowledge about ways of structuring information in Anglo-Saxon riddling practice with regard to the order of constituents which form the comparative pattern: Subject, Object of comparison, basis and marker. Considerable attention is given to the object and basis of comparison because of their information value as opposed to the subject of comparison, being obscured.

\section{Results.}

\subsection{The taxonomic Status of Clauses Containing Comparisons.}

Due to contaminated semantics of comparative clauses, their taxonomic status is still not agreed upon. They are viewed either as separate comparative clauses or as belonging to clauses of manner which are included into a broader group of adverbial clauses (for more details, please, see COBUILD, 2011: 672). The comparative clauses can roughly be grouped into those where things / objects / notions of the same quality are compared (as ...as, like, the same) and those where things of different amount of quality (Comp. degree Adj. than; superlative Adj in / of) are compared. Comparative clauses can be viewed as an example of economy of effort, being a basic cognitive activity comparisons cut the distance of getting new knowledge (Kharitoncik, 2004: 23) because new, unknown, unusual is understood by comparing with old, known, trivial. Being the basic sourse of knowledge, comparisons make it possible to pick one trait of things and look for similarities or differences between them. Together with analogy, deductive and inductive reasoning, comparison is a universal tool and can be observed in language (Vorkachev, 2013:2,86). Comparison is a unique operation which is not restricted to one level of language hieararchy, i.e. it is not only syntax where comparison can be observed. Words like bullish, bearish, sheepish, bossy, manly, comparative structures like as...as, metaphors are the examples of explicit or implicit comparison manifested at various language levels. 


\subsection{Structure of Comparative Clauses of Inequality.}

Comparative clauses of inequality are thought to constitute four members: subject of comparison, object of comparison, basis for comparison and the marker of comparative relations (see Ikalyuk, 2010). In this paper the members of comparison are viewed with respect to information packaging: subject - new, unknown; object - old, known, to which the riddler directs attention, basis for comparison - a selected property of a subject possessed by the object and in the context of this research is expressed by an adjective in the comparative degree. E.g.:

\section{Subject is Basis [Adj. comp. degree] THAN object.}

In other words, [NP] is usually the topic, known, presupposed, textually bound. New information is within [VP] group. Such allocation of 'subject new / unknown - object old / known' in OE riddling practice contradicts the point of view that schools of thought more or less assume. Topic identification does not rely only on formal criteria, grammatical subjects are not necessarily topics (as in expletives) and grammatical subjects are not exlusively topics. In riddles it is the subject that is to be guessed, it cannot be restored anaphorically, there are no contextual links to it in the text. By definition, it is the object in VP which is to carry out this function. Futhermore, it complies with the standard allocation of information within a sentence: old before new. But when we consider OE riddling practice, the things do not seem to be that definite.

Let's have a closer look at the structure of the comparatives in OE. In the example (2) taken from Riddle 40, line 50: (2) Ic eorpan eom aeghwoer braedre = I earth am everywhere broader $=I$ am everywhere broader than the earth, the subject Ic, the object eorpan, basis for comparison brcedre. Topic Ic is immediately followed by focus eorpan which in its turn is followed by the verb. So this structure is archaic, replicating PIE and Common Germanic word order SOV. In the following example, (3) hefigere ic eom micle pōn se hara stan = Heavier I am much than the gray stone = I am far heavier than the gray stone the subject ic (I), the object - hara stan (gray stone), the basis - hefigere (heavier). Topicalization (or 'focalization' to be more terminologically accurate) of hefigere is a movement of the constituent to sentence initial position with the aim to highlight the property of the object gray stone. The structure of the said comparisons testifies to the fact that the order of the constituents in $\mathrm{OE}$ comparisons was not fixed. If we conventionally number these constituents in order they should appear in Modern English as 1 Subject - 2 Ground / Basis THAN 3 Object, then OE comparisons in riddles allow possible ordering: 132, 31 MARKER DŌN 2, as illustrated in (2) and (3). The marker pōn is non-binding as in Riddle 40, line 38: Hyrre ic eom heofone $=$ higher I am than heaven .

\subsection{The Information Packaging of Comparisons in OE Riddling Practice.}

There is general agreement among scholars that the linear order of sentence constituents is largely the result of the informational dichotomy: old $: \because$ new, i.e. the speaker and the hearer are prepared to en/decode information according to what is contextually known and what is new. Intonation is another telltale sign of determining contextually new and old information in the message but in diachronic research it seems inaccessible, and is not possible to be taken into consideration. Information packaging (Chafe, 1976: 28) is described as the way the message is sent, this is the prioritized aspect and the message itself is the secondary issue. It is now axiomatic that the sentence is of binary character and is partitioned into focus - ground (also known as focus - topic, rheme - theme, new - given etc.). This partition is central in information packaging and is elaborately highlighted in 
various schools of thought (see Erteschik-Shirt 1986, Wilbur 2012, Hinterwimmer, 2019, Roberts, 2019, Ward and Birner, 2019 inter alia). Focus - ground is like a step forward combined with a step back in information packaging. A step back (ground) is either textually / discourse bound anaphoric reference or interlocutors' experience, shared knowledge of reality. The focus (a step forward), is generally viewed as the most salient discourse entity. Referents in focus are those ones, known to the hearer, that are in some sense activated or salient. Focus is associated with new, rheme. The function of focus is to provide new information about topic and to draw the addressee's attention to it (Wilbur, 2012: 473). Ground is associated with old, and termed differently by scholars: theme (Firbas, 1964), presupposition (Chomsky, 1971), background (Daht, 1974), topic (Hajikova, 1984), old information (Halliday, 1967; 1985), open proposition (Prince, 1986). Focus information is marked in the sentence. It is the position to the verb that is relevant for identifying the sentence segment as marked. Thematic position is usually preceeding [VP], being sentence initial whereas rhematic, new information is postverbal. In other words, the most important information goes last.

But at the same time it is not always the case that the sentence initial position acts as a link to the previously stated information and can introduce new information in a communication event (for more details, please, see Geurts, 2019: 481 - 510). In the Germanic languages the fixed word order was triggered due to systemic changes which resulted in SVO structure, now a dominant English word order pattern with subject (ground) initial and object (focus) final, reflecting the tendency to package information in the order 'given - new'. Given / old information is expressed early in the sentence and precedes new information. It is viewed as iconic: old before new (Haiman, 1983: $781-819$ ).

\subsection{Thematic Progression in Comparative Clauses in OE Riddles.}

The dynamics of information flow, thematic progression, according to Frantishek Daneš (1974) can be of three types: 1) keeping the theme constant, 2) deriving the theme from the previous rheme, 3 ) deriving the theme from the 'hypertheme'. Keeping the theme constant is defined by Nomi Erteschik-Shir as 'topic chaining' (Erteschik-Shir, 2007: 2-3), i.e. the same topic appears as anaphoric reference to the one in the previous sentence. In doing so the same topic is maintained throughout the communicative event. In this article I will dismiss the second and third types of thematic progression, which appear to be scarce in the sentences containing comparisons in OE riddles. For insntance, in riddle 33 (31) the topic rotates around the riddling entity (an Iceberg), though it is referred to as mother, daughter, she (4), still the riddlee knowing the rules of the game and abstracting from direct reference (mother - daughter) wades through tangled descriptions in an effort to assess those vague, misleading and allegoric foci, to guess the topic. Riddles in OE is perceptual and mental exercise with strongly present descriptive element, which enables the riddlee to glimpse beyond the veil of the material world, to reveal the hidden nature of things (Paz, 2017: 16). E.g.:

(4) "Is min modor mogða cynnes 10 poes deorestan, poet is dohtor min eacen up liden; swa poet is aldum cup,

firum on folce, poet seo on foldan sceal on ealra londa gehwam lissum stondan."
Is my mother of maiden kind

The dearest, that is daughter of mine powerful sails up, so that is by old known among the folk that she shall come joyfully to all land on each in peace stand

"My mother the dearest of women; she is my daughter grown up powerful. It is known to old men, to folk among all people, that she shall come up beautifully and peacefully everywhere in the world." 


\subsection{Universal and Unique Specificity of Riddling Practice.}

Riddling appears to be a historically constant cultural universal, but the content and structure of the riddle is likely to be diachronically and culturally variable. Latin and OE riddling traditions tend to lend animateness to things, known among scholars as prosopopoeia, a figure of speech in which an abstract thing is personified; an imagined, absent or dead person or thing is represented as speaking (Oxford Dictionary, 2010: 1426).

The OE riddle typically consists of unnamed riddling entity (a wiht), it can be either a single word or some binominal and its semantically diffuse description, containing allegory, parables, indirect reference, hints, metaphors, euphemisms, vague comparisons and patchy explanations which only sketch in a dotted line the contours of the possible solution. In this research, the riddling entity is understood as a thing or living being, substance or abstract notion which is the subject of description, something which is to be guessed / solved by the riddlee.

In riddling discourse practice the answer is usually restricted to one and only one correct option. But when it comes to OE riddling tradition, there can be literal and allegoric answers like: a) fish in the river and b) soul in the body (Riddle 43); a) bookworm, bookmoth and b) maggot and psalter (Riddle 47); or double entendre of Riddle 45 a) parallels of erotic character and b) making dough. In other words, the riddle sometimes presupposes double reading. In some cases, riddling entity (the subject/topic) is named as afore mentioned mother, daughter or less definite 'stealing guest' in Riddle 42 (K-D 47) (5). But it is more often the case when the narration can be first person (ic, me) as in Riddle 40 (6), or the thing can be referred to using third person deixis, e.g. he, and things, artifacts, animals, take on human voices (prosopoeia). E.g.:

(5) Stalgiest ne waes wihte py gleawra, pe he pam wordum swealg.

The stealing guest was not at all the wiser for that, for those words which he swallowed.

(6) Ic eom faegerre frcetwum goldes | peah hit mon awerge wirum utan | Ic eom wyrslicre pōn pes wudu fula | оððе pis waroð pe her aworpen ligeð

Fairer I am than ornaments of gold, | although they be covered with delicate work. II am filthier too than this foul wood | or this seaweed that lies cast up here.

In the riddles the comparisons are far from serving the purpose to give a clear idea about a thing or a living being, they are hints and do not help to get information prematurely, allowing the recipient to sift for possible solutions. Another interesting feature of OE riddles is that hyperobjects often act as subjects of riddling. These hyperobjects are elusive, incomprehendible, spanning massively in time and space, they are present and absent at the same time (rain - raindrops are a single manifestation of elusive 'climate') (see more on this in James Paz, 2017).

As was aforementioned, comparison is traditionally viewed as an economical way to inform the addressee about some fragment of reality. Riddles conform to a model of communication made up of a code and an encoded message that is first transmitted and then decoded. It is a directed thinking. The speaker refers to the property of the already commonly known thing, action or state. The riddle creatures are not palpable, they are elusive, shape shifting and provoke the reader to think in the given direction, to learn the nature of things, to get used to the idea that things in the world can speak for themselves, and such constant notions as age, gender, space can be diffuse and not certain. Very often the property of a thing chosen for comparison is based on traditional, routinely accepted social stereotype. For example, in a given society something / someone is attributed to be big, small, sly, wise, brave, angry, swift, bright, fat, smelly. And this feature can serve the point of reference, 
which is not necessarily textually bound often being of exophoric (relying on life experience of communicators) character.

OE riddling practice allows comparisons as the basic syntactic building block reinforced by lexical cohesion usually of antonymic character as in the brilliant example is Riddle 40, containing over 100 lines (!) and 15 pairs of adjectival antonyms. And not so many synonyms: broader - wider (lines 50-51). The adjective antonyms are actually textholders in the riddle in question, with comparatively distant occurance step of the opposite word (the span is usually 2-3 lines (hereinafter $l$. in this passage) apart from each other). Cf: l.16 blead = cowardly, timid $-l .18$ cenra $=$ bolder; $l .26$ delicate $-l .31$ foul, l. 38 Hyrre $=$ higher $-l .41$ under eorpan $=$ under the earth, $l .42$ yldra $=$ older $-l .44$ geong $=$ young, $l$. 46 fagerre $=$ fairer $-l .48$ wyrslicre $=$ viler, $l .74$ Hefigere $=$ heavier $-l .76$ leohtre $=$ lighter, $l .78$ heardre $=$ harder $-l .80$ hnescre $=$ softer. In Riddle 40 comparisons is the major force in topic chaining and in keeping the theme constant by developing rheme.

The specificity of the riddle is comparable to some extent with deixis (pointing without naming). But in riddles, it is describing without naming. Direct transfer of information is blocked in accordance with the restrictions of the genre. According to Pepicello W.J. and Green Th.A. (1984), the riddlee should be incapable of solving riddles posed by the riddler (Pepicello and Green, 1984: 21). Thus, the content of the riddle balances between said and unsaid, transparency and vagueness. Linguistic ambiguity of riddling allows multiple interpretations of the ingoing message violating P. Grice's maxims of quality and manner, whereas during normal conversation the speaker as a rule strives for clarity thus satisfying the said principles of communication. As such the riddles are intentionally user-unfriendly, or half-friendly, reflecting the riddler's attempt to confuse the riddlee. The information sought by the riddlee is to be derived from the past experience, being of exophoric character. The riddles are timeless. They are not restricted in space or time i.e. they cannot be predicated in spatio-temporal parameter; they are not situational.

The specificity of comparisons in OE riddles can obtain more distinct contours if contrasted with other Old Germanic sources, eg. with those in Völuspá if we abstract ourselves from minute details. The said riddles share some common features but at the same time they differ in their function and in the way the world is presented (cultural aspect). ON comparisons based on inequality serve and support the general didactic idea of Edda. What meets the eye is the antithesical character of the issues compared in $\mathrm{ON}$, eg. the lack of praying vs its overabundance: (7) Betra er óbeðit en sé ofblótit, (Völuspá, 145)); lack of something is better than abundance: (8) betra er ósent en sé ofsóit (ibid., 145)). The subject and object of the said comparisons are semantically homogenious units sharing the same broader topic in termes of their belonging to abstract vs concrete notions: abstract $:$ abstract as eg. burden - wisdom: (9) Byrði betri berr-at maðr brautu at en sé mannvit mikit; auði betra pykkir pat í ókunnum stað (ibid., 10); concrete - concrete: a hall-shining sun Sal sér hon standa sólu fegra (ibid., 64), a house / a hut - lack of accomodation. OE comparisons of inequality in the riddles are built on the same principle as well. The compared units are on the same line correlating with abstract - concrete notions, eg. abstract sundorcrceft (= art) in Riddle 4 is compared with the diffuse formulation than any men know (10) sundorcraft hafa eth maran micle pōnne hit men witen = special art has it more become greater than it men know = translation: A special power it has more greater than any men know. In Edda subject-object relations in comparisons of inequality do not serve the purpose to make the ingoing information easier either. Their function is purely didactic being adjusting or admonishing in character. The abstractedness of such comparisons is readily detected despite concrete and down-to-earth constituents used for comparing (subject-goats, patched roof, a 
hut; the object - begging). The basis for comparison in $\mathrm{ON}$ is diffuse and is predominantly betra - 'better'.

The correlation between abstract-abstract or concrete - concrete subjects and objects (regularly observed in ON Völuspá), is not so definite in OE riddles. In Riddle 40, solved as abstract Creation, the abstract riddling entity is compared with a concrete plant 'lily': ic eom betre ponne heo $=I$ am better than she (line 28). Abstract property 'brevity' (basis for comparison) is compared with concrete object 'wild boar' (line 19). The prosopopoeic narrator (the riddling entity is identified as such through 1pers singular verb 'eom') is compared with concrete wild boar in a certain situation: (11) ond eofore eom oeghwoer cenra, ponne he gebolgen bidsteal giefed (Riddle 40, 19). And wild boar am everywhere fiercer than he angry stand gives = [I] am bolder than a wild boar, when he, enraged, makes a stand.

\subsection{Anglo-Saxon Priorities and Values as Viewed in Comparisons of OE Riddles.}

Pre Christian or early Christian period in Germanic culture reveals different priorities and values of the Germanic people. OE eofre (ON jøfurr) cited in (11) supplanted in c.1300 by 'wild boar' (jøfurr from the Proto-Norse “*eburaR”, meaning 'chief, king' developed from 'wild boar', which is either amelioration of the meaning or metaphor in terms of Leonard Bloomfield's classification of semantic change. Here the demarcation line between the two is fairly thin). It is now not commonly known that due to the association of bravery men and women sometimes receive(d) names with the element ON jøfurr, OSaxon: evur; OE: eofor in it: Everard (= lit. strong boar) in English; Eofor, son of Wonred, was a Geatish warrior in 'Beowulf'; OE Eoforwine = friend of boars, Modern English Irwin (Dictionary of Etymology URL: https://www.etymonline.com); OHG Eberhard; ON Jofurr, Iafri etc. Contrastingly cf negative, derogatory meaning of 'pig' and derivatives developed beginning from Middle English onwards: piggish, pigsney, piggledy, peccary. Domesticated pigs on the contrary are not so much admired in the Anglo-Saxon society and traditionally featured parametrically (big, fat) as in Riddle 40: (12) Mara Ic eom ond faettra pō amoested swīn [...] Bigger I am fatter than masty swine = I am bigger and fatter than the masty swine [...] .

Comparisons in OE riddles shed some more light on the way the world was modeled and categorized in the distant past. The basis for comparison includes notions related to parameter (size, height), sense perception (taste, odour, tactile quality, etc.), speed, emotions and feelings. Surprisingly, salt serves as the model of sharpness: (13) smeare pōn sealt (= sharper than salt) (Riddle 91); handworm which causes scabies is the model of tiny size: (14) lasse pōn hond-wyrm (Riddle 12 (K-D 66)) = smaller than a handworm, as opposed to Biblical mustard seed eg. in Goth. kaurno sinapis: galaubein swe kaurno sinapis (CA Mark 4:31; CA Luke 17:6, URL: http://www.wulfila.be/gothic/browse/); the whole world / earth is the model of vastness in Riddle 12: (15) Ic eom mare pōn pes mindan geard [yard, land] = I am greater than this world; and in Riddle 40 (38): (16) Ic eorpan eom ceghwoer bradre ond widgielra pōn pes wong grena folm mec mag bifon = I am broader than the world and everywhere and wider than this green meadow. In the Riddle 12 solved as Quill pen the swiftness of a bird synecdochically serves the basis for comparison: (17) swift woes on fore fulgum framra = Swift was its moving, faster than birds. Incense and the rose are the model of fragrance in Riddle 40: (18) Ic eom on stence strengrepōn ricels oppe rose sy...on eorpan tyrf $=$ My fragrance is stronger ...than any incense or any rose in the field of earth... [lines 23-24]. The whale is referred to as the example of big size and strength: (19) Mara ic eom ond strengra ponne se micla hwal: bigger I am stronger than a large whale = I am greater and stronger than the large whale [ibid., line 92]. Frost is viewed to be the point of 
reference of coldness and hardness: (20) heardra ic eom ond caldra pōn se hearda forst $=$ harder I am and colder than the hard frost [ibid., Riddle 40-38, line 54].

When it comes to the bases of comparison of the moon and the sun, there is more to the story, than meets the eye. The riddling entity (Creation) in riddle 40 (38) is compared with brightness of the moon: leohtre ponne mona; = brighter than the moon; and the agility of the sun: swiftre pon sunne = swifter than the sun. This is the reflection of Germanic prioritizing of the moon over the sun. The sun was attributed to play the secondary role, as the moon's inferior companion: Sól varp sunnan, sinni mána = Sun shone from the south, moon's companion (ON Völuspá, 5). According to etymological findings, the moon got the name prior to the sun and the latter of the two derived its name from the former (Taranets, 2008: 145 - 146). In English the noun 'sun' was of feminine gender well until the $16^{\text {th }} \mathrm{c}$. and since then masculine prevailed; whereas the noun 'moon', being senior, had masculine gender. The said reflects the hierarchy in patriarchal society as it was. The moon was considered more important than the sun probably because the former appears when it is dark and helps wayfarers by lighting their way. Besides, the moon and the sun both were the points of reference of time and space (lunar calendars, cf moon - month, position of the sun as the marker of time and season). Thus, the agility of the sun was not at all randomly picked as the basis for comparison.

\section{Conclusions.}

Information packaging of comparative clauses in OE riddles violates the "old is followed by new" principle. The riddling entity usually goes first but is behind the veil of personal deictics or semantically obscure 'wiht'. It is not known, it is both given and to be guessed. The second part, which is supposed to be new relies on exophoric reference. They provoke critical thinking but do not fill the gap in knowledge about the riddling entity. The riddler sounds uncertain, misleading, vague and is not cooperative with the potential riddlee, whose intention is to guess, decipher, identify, unveil. The dynamics of information flow unfolds within the model of topic chaining, i.e. the same theme remains constant and focused from different angles.

The structure of $\boldsymbol{O E}$ riddles is formed by three obligatory (subject. object, basis) members and one optional - the marker. The order of these members is not fixed. The object and basis for comparison can be topicalized.

In $\mathrm{OE}$ riddling practice comparisons function not to economically give the proper understanding of an uncommon, new thing / reality / action / living being. Rather their usage is misleading, vague and intentionally tangled so that the hearer is faced with difficulty to have a clear understanding of the property of the item introduced. It's a guessing game and the answer is not readily apparent, the recipient should look into inner characteristics of things / actions / human beings.

The comparisons in OE riddles can be culturally loaded with hidden senses and may be incorrectly interpreted by an unprepared reader. The interesting point about the comparisons of inequality in $\mathrm{OE}$ riddles is that they reveal unexpected and intricate parallels between objects or notions thus creating many possible solutions of the riddle.

Abbreviations

Goth. - the Gothic language

OE - Old English

ON - Old Norse

SVO - Subject Verb Object 


\section{References}

Bosworth-Toller Anglo-Saxon Dictionary. http://www.bosworthtoller.com/

Bunijatova, I. (2003). Evoljucija ghipotaksysu v ghermansjkykh movakh (IV-XIII st) [Evolution of Hypotaxis in Germanic Languages (IV-XIII centuries)]. Vydavnychy Tsentr KNLU.

Cavell, M. (2018). The Exeter Book riddles in context 31 Jan 2018 Retrieved 12 August 2020. $\mathrm{https} / / / \mathrm{www} . b l . u k / m e d i e v a l-l i t e r a t u r e / a r t i c l e s / t h e-e x e t e r-b o o k-r i d d l e s-i n-c o n t e x t$

Chafe, W. L. (1976). Givenness, contrastiveness, definiteness, subjects, topics and point of view. In Charles N. Li (Ed.), Subject and Topic (pp. 27-55). Academic Press. Publishers.

Sinclair, J. (Ed. In Chief) (2011). Collins Cobuild English Grammar, 3d edition. Harper Collins

Fulk, R. D. (2018). A Comparative Grammar of Early Germanic Languages. Putnam, M.T.; Page B.R. (Eds); Smith L.C. - John Benjamin's Publishing Company.

Geurts, B. (2019). Accessibility and Anaphora: in Semantics - Sentence and Information Structure Eds Paul Portner, Claudia Maienborn and Klaus von Heusinger Series: Mouton Reader Mouton de Gruyter. 481-510. https://doi.org/10.1515/9783110589863

Glosbe DICTIONARY. https://glosbe.com/ang/en/eofora

Haiman, J. (1983). Iconic and economic motivation. Language, 59(4), 781-819.

Haritonchik, Z. A. (2004). Sravnenie v processah jazykovoj nominacii [Comparison in the processes of language nomination]. Ocherki o jazyke. Teorija nominacii. Leksicheskaja semantika. Slovoobrazovanie.

Ikaljuk, L. M. (2010). Porivnjaljni konstrukciji v tekstakh davnjoanghlijsjkoji movy: strukturnyj $i$ funkcionaljno-semantychnyj aspekty [Comparative Constructions in Old English Texts: Structural, Functional, and Semantic Aspects]. Thesis.

Lehmann, W. P. (2005-2007). A Grammar of Proto-Germanic. In Slocum, J. (Ed.) Linguistics Research Center, University of Texas at Austin.

Möhlig-Falke, R. (2016). Using the Dictionary of Old English Corpus for linguistic analyses A basic classification of the textual sources, Neuphilologische Mitteilungen. Retrieved January 2016 https://www.researchgate.net/publication/307852792

Nevill, J. (2011). The Unexpected Treasure of the 'Implement Trope': Hierarchical Relationships in the Old English Riddles. The Review of English Studies, 62(256), September 2011, (pp. 505-519). https://doi.org/10.1093/res/hgq131.

Oxford Dictionary of English (2010). Angus Stevenson (ed.). $3^{\text {rd }}$ edition OUP.

Paz, J. (2017). Nonhuman voices in Anglo-Saxon literature and material culture. Manchester University press.

Pepicello, W. J., \& Green, Th. A. (1984). The Language of Riddles. New Perspectives. Ohio University Press.

Hinterwimmer, S. (2019). Information Structure and Truth Conditional Semantics. In P. Portner, C. Maienborn, K. von Heusinger (Eds.), Semantics - Sentence and Information Structure (pp. 339-380). Series: Mouton Reader Mouton de Gruyter. https://doi.org/10.1515/9783110589863

Cole, P., \& Prince, E. (1981). Toward a taxonomy of given-new information. Syntax and semantics. Radical Pragmatics, 14, 223-254.

Roberts, C. (2019). Topics. In P. Portner, C. Maienborn, K. von Heusinger (Eds.), Semantics Sentence and Information Structure (pp. 381-412). Series: Mouton Reader Mouton de Gruyter. https://doi.org/10.1515/9783110589863.

Stanton, R. (2015). Mimicry, Subjectivity, and the Embodied Voice. In Irit Ruth Kleiman (Ed.), Anglo-Saxon Bird Riddles / Voice and Voicelessness in Medieval Europe. (pp. 29-43). Palgrave Macmillan https://doi.org/10.1007/978-1-137-39706-5

Swart de, H. and Hoop de H. (2000). "Topic and focus". In L. Cheng and R. Sybesma (Eds.), The First Glot International State-of-the-Article Book (pp. 105-130). Berlin / New York: Mouton de Gruyter.

Taranecj, V. Gh. (2008). Diakhronija movy [Diachrony of Language]: zbirka statej: vydano do 70richchja vid dnja narodzhennja prof. Tarancja Valentyna Ghryghorovycha uchnjamy juviljara. Drukarsjkyj Dim. texts.com

The Complete Corpus of Anglo-Saxon Poetry. Retrieved August 2, 2020 https://www.sacred-

The Gothic Bible: Retrived August 10, 2020 http://www.wulfila.be/gothic/browse/

Vorkachev, G. S. (2013). Studia selecta: izbrannye raboty po teorii lingvokul'turnogo koncepta [Studia Selecta: Selected works on the theory of linguocultural concept]: monografija. Paradigma. 
Ward, G., \& Birner, B. J. (2019). Discourse Effects of Word Order Variation. In P. Portner, C. Maienborn, K. von Heusinger (Eds.), Semantics - Sentence and Information Structure (pp. 413-449). Series: Mouton Reader Mouton de Gruyter. https://doi.org/10.1515/9783110589863.

Wilbur R. B. (2012). Informarion Structur. In R. Pfau, M. Steinbach, and B. Woll (eds), Sign Language. An International Handbook (pp. 462-489). Berlin: De Gruyter Mouton.

\section{Бібліографічний опис:}

Калитюк $\Lambda$. П. (2020) Інформаційна структура порівнянь нерівності в загадках давньоанглійської мови. Науковий часопис Національного педагогічного університету імені М. П. Арагоманова. Серія 9. Сучасні тенденції розвитку мов, 20. 64-74. DOI: https://doi.org/10.31392/NPU-nc.series9.2020.20.05

\section{Анотація}

Дослідження спрямоване на вивчення іформаџійного наповнення компаративних структур нерівності у загадках давньоанглійської мови The Exeter Book X cm. Установлено, щяо порівняння не виступають як економний спосіб представлення нової інформачії. Навпаки, вказані структури $\epsilon$ засобом для переобтяження, заплутування та спантеличення рециипіснта з метою блокування легких иляхів відгадування загадки. Суб'єкт загадки, хоч інколи й неістота, самоідентифікується через розмиті семантично дифузні особові дейктики (прозопопея). 3'ясовано, щяо канонічний принцип інформачійної структури («старе передує новому») порушується в порівняннях давньоанглійських загадок, оскільки старе, відоме у загадках, виступає невідомим. Інформачійне наповнення порівнянь нерівності у названих загадках набуває такої форми: «невідоме рещипіснту + нове, але відоме $з$ попереднього досвіду». Інформація представлена у такий спосіб, щоб задіяти екзофоричний (часто з культурною складовою) контекст відгадувальника. Для виявлення специфічних рис давньоанглійських компаративів нерівності у статті подекуди містяться звернення до відповідних структур готської та давньопівнічної мов.

Ключові слова: давньоанглійські загадки, інформаційне наповнення, інформачійна структура, компаративи нерівності, прозопопея. 